\title{
IMPACT OF INITIAL ENVIRONMENTAL CONDITIONS ON GERMINATION, GROWTH, AND DEVELOPMENT OF Cucumis sativus at LAMJUNG
}

\author{
A. Chapagain* and A. Khanal \\ Lamjung Campus, Institute Of Agriculture And Animal Science \\ *ashcha95@gmail.com
}

\begin{abstract}
Cucumber is the fourth most important vegetable crop worldwide favored for its edible fruit. Cucumber cannot be grown in the winter months due to its intolerance to cold and frost. An experiment was conducted in IAAS, Lamjung to test the effectiveness of various nursery raising conditions for achieving earlier harvest in spring. Three treatments viz. cold frame, hotbed, and open were selected and replicated 30 times each. Data on germination speed, germination percentage, true leaf initiation, plant height, tendril initiation, days to first flowering, days to harvesting, length and diameter of fruit and fruit yield were recorded. Hotbed achieved earlier germination ( 8 days) followed by cold frames ( 8.57 days) and open (12.73 days) respectively with cold frame having the highest germination percentage (98\%) followed by a hotbed (96\%) and open (90\%). True leaf initiation was earlier in a cold frame ( 21.5 days), followed by hot bed (22.83 days) and open (30.97 days). Transplanting of cold frame and hotbed seedlings could be performed 10 days prior to open. Final height attained was significantly maximum for cold-frame plants $(97.93 \mathrm{~cm})$ and minimum for a hotbed $(76.19 \mathrm{~cm})$ with open being indifferent $(86.17 \mathrm{~cm})$ to cold frame and hotbed. Days to tendril initiation, days to flowering and days to first harvest were $57.52,66.87$ and 82.93 days respectively for cold-frame which was significantly minimum compared to hotbed (64.04, 70.38 and 86.95 days) and open $(65.73,71.23,85.58$ days), both being indifferent. Significantly maximum yield was obtained from cold-frame $(1465.73 \mathrm{~g})$ with open yielding significantly minimum $(1004.06 \mathrm{~g})$ and hotbed being indifferent $(1122.45 \mathrm{~g})$ to cold frame and open. Cold-frames are found to be comparatively effective to hotbed and open condition with 3.12 days earlier and $35 \%$ higher yield.
\end{abstract}

Keywords: cold-frame, Cucumis sativus, hotbed, nursery, temperature

\section{INTRODUCTION}

Cucumber (Cucumis sativus L.) is the fourth most important vegetable worldwide (Lv et al., 2012) widely appreciated for its fruits. On the basis of use, cucumbers can be classified as slicing type, pickling type and burpless type. According to Arykroyd (1941) cucumber consists of $96.4 \%$ moisture, $0.4 \%$ protein, $0.1 \%$ fat $2.8 \%$ carbohydrate $0.3 \%$ mineral matter (Calcium $0.01 \%$, Phosphorus $0.03 \%$ and Iron 1.5mg per $100 \mathrm{gm}$ ), Vitamin B 30IU per $100 \mathrm{gm}$, Vitamin C 7mg per $100 \mathrm{gm}$. Ameliorative activity (Vishwarath, Patel, Kandile and Bhise, 2012) hypoglycemic and hypolipidemic (Sharma, Khan, Akhter, Alam, Ahmed et al., 2013), carminative and antacid properties (Sharma, Pwodedi and Pawal, 2012) are known to be possessed by cucumber.

Cucumber, a warm season crop is easily injured by frost but can tolerate slightly cooler temperature than other members of its family Cucurbitaceae (Shoemaker and Teskey, 1969). To achieve the benefit of early crop, skipping extreme cold temperature, forcing structure in nursery is used. Forcing structures aid in increasing the length of growing season (Thompson \& Kelly, 1985).

Cold frames are nursery raising structures comprised of soil bed on the ground enclosed by side walls or frames which are $20-30 \mathrm{~cm}$ in height. The frame can be covered with glass, plastic, or other transparent or translucent materials (Thomas, Schmidt and Jensen, 2013). Solar heat is the source of energy (Kumar, Tiwari, Kumar and Pandey, 2006). They are generally used in pre-spring nursery raising (Denisen, 1958). 
Hotbeds are nearly identical to cold-frames but have an additional source of heat supply. Excavations are made below soil surface for placement of lignocellulosic materials (Denisen, 1958). The lignocellulosic material generates heat on decomposition (Thomas, Schmidt and Jensen, 2013).

Cucumber being a warm season crop cannot be grown in winter months but the demand is year round. Offseason production of can be done for maximization of profit, substituting import and making it available year round. However, farmers of Nepal are resource poor and cannot afford a greenhouse for offseason production of cucumber so, in the context of Nepal in mid-hill region hotbed and cold-frames are extensively used. Research is lagging in case of effectiveness of these structures in the particular climate for early crop production of cucumber. The research was carried out to check the effectiveness of various nursery raising environment in the climate of Lamjung and find out their impacts on respective crop attributing parameters.

\section{MATERIALS AND METHODS}

The experiment was conducted in Horticultural farm of Institute of Agriculture and Animal Science, Lamjung Campus. The experiment was conducted from $8^{\text {th }}$ January, 2018 to $16^{\text {th }}$ April, 2018. Cucumis sativus variety Kamini was choosen due to its easy availability and being popular among farmers in the research area. Three treatments viz. cold-frame, hotbed and open with 30 replications for each treatment were arranged in RCBD design, in the field condition. 50 seedlings were raised in each treatment in nursery. Observation of temperature range, days to germination, days to true leaf initiation and days to transplanting was done. After transplanting Cucumis sativus, fungicide application (SAAF: Carbendazim-12\% and Mancozeb-63\% WP) was done on the day of transplanting. Regular irrigation was performed as per water requirement. Fertilizer application was performed 15 days after transplanting at the rate of $14.653 \mathrm{gm}$ urea, $4.897 \mathrm{gm}$ DAP and $9.375 \mathrm{gm} \mathrm{MOP}$ per plant. In the field, observations of plant height, days to tendril initiation, days to flowering, days to harvest, length \& diameter of fruit and yield was done.

Data entry and graphs were created using MS Excel 2007. GenSTAT $15^{\text {th }}$ Edison was used for statistical analysis. The results were subjected to ANOVA followed by Duncan's Multiple Range Test (DMRT) at significance level of 0.05 .

\section{RESULTS AND DISCUSSION}

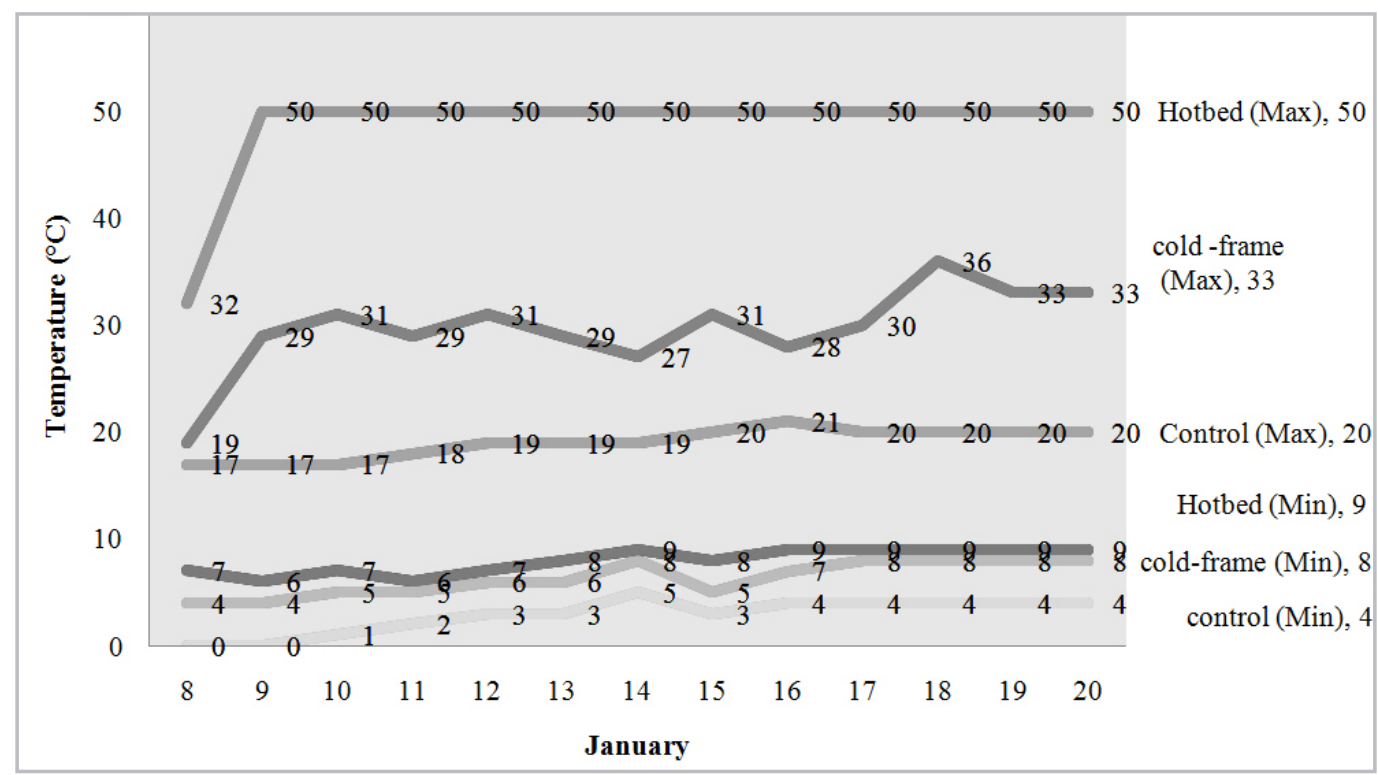

Figure 1: Temperature range of nursery environment during January, 2018 at IAAS, Lamjung 
The temperature range was higher for hotbed with maximum temperature of $50^{\circ} \mathrm{C}$ and minimum $6-9^{\circ} \mathrm{C}$. Decomposition of cattle dung (lignocellulosic material) raised the temperature of hotbed to that level along with solar radiation. Temperature range of cold-frame was maximum $28-33^{\circ} \mathrm{C}$ and minimum $4-8^{\circ} \mathrm{C}$. Solar radiation was the factor for increasing temperature. Open condition had the lowest temperature range. Maximum temperature range was $17-21^{\circ} \mathrm{C}$ and minimum temperature range was $0-4^{\circ} \mathrm{C}$. The humidity was $100 \%$ for hotbed and cold-frames as they were airtight with no ventilation. The open humidity fluctuated but was lower than $100 \%$ except during rainfall.

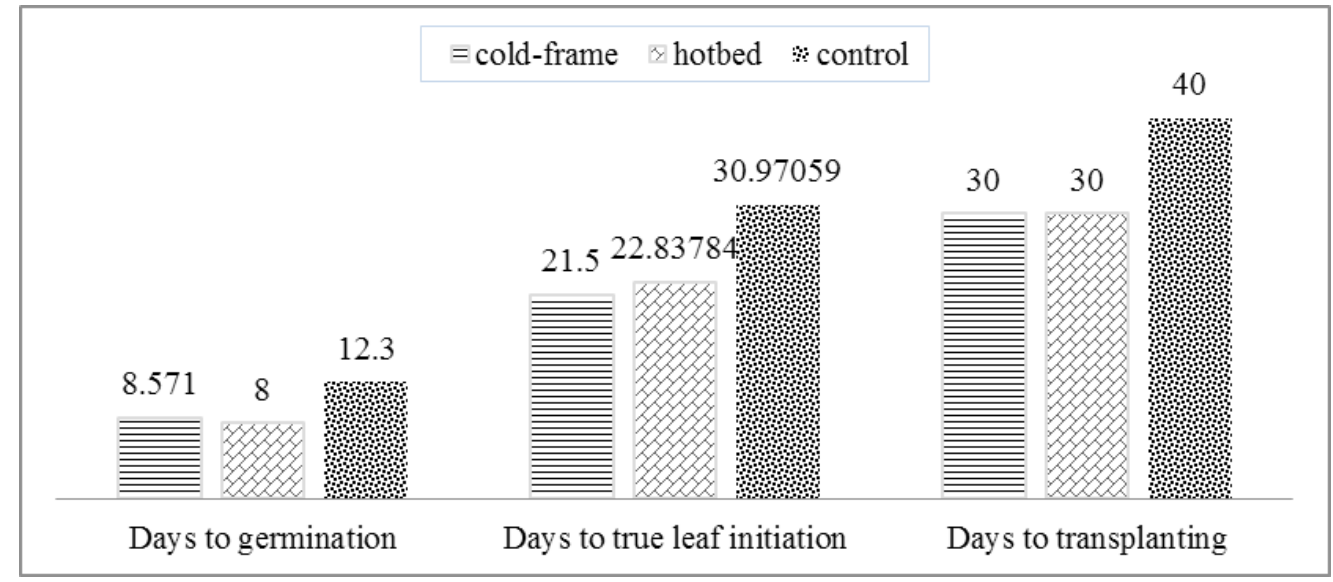

Figure 2: Effect of nursery conditions on days to germination, days to true leaf initiation and days to transplanting of cucumber seedling during Jan and Feb, 2018 at IAAS, Lamjung

Average days to germination was observed earlier in hotbed (8 days) followed by cold-frame (8.57 days) and open (12.73 days). Whereas, true leaf initiation was earlier in cold frame (21.5 days) in comparison to hotbed (22.83 days) and open (30.97 days) (figure 2).

Cold-frame had the highest germination percentage (98\%) followed by hotbed $(96 \%)$ and open $(90 \%)$. Earlier germination was due to highest altering temperature in hotbed $\left(6 / 9^{\circ} \mathrm{C}-50^{\circ} \mathrm{C}\right)$. Altering temperature is faster and strong inducer of germination than low temperature ranges (Markovskaya and Sysoeva, 2004).

Lower temperature causes denaturation of protein and inactivation of

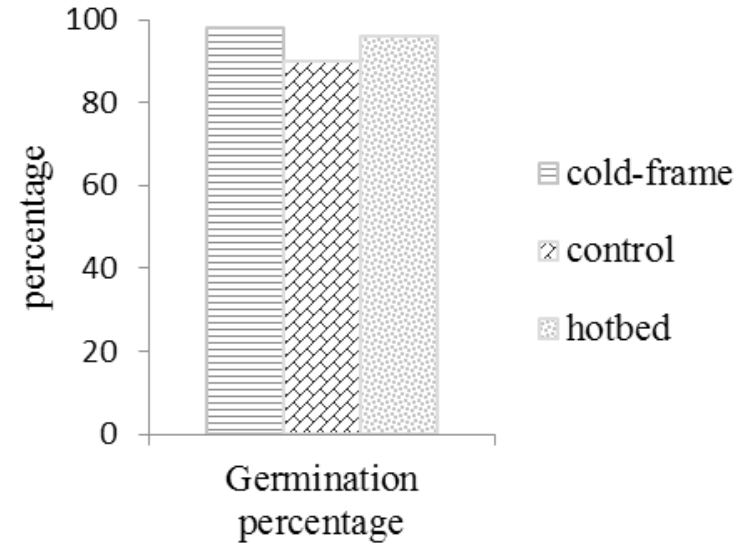

Figure 3: Effect of nursery condition on germination of cucumber seedling during Jan, 2018 at IAAS, Lamjung enzymes inhibiting germination (Simon et al., 1976). Leakage of minerals is also caused at suboptimal temperature range (Russo and Biles, 1996). Days to true leaf initiation was earlier in plants of cold-frame and was followed by hotbed and open. Seedlings grown at higher temperature range than optimum develop divergent physiology than normal seedling in terms of higher transpiration rate.

When enclosed in hotbed seedlings had checked transpiration rate due to high humidity $(100 \%)$. When opened, the physiology remained constant but ambient humidity decreased which promoted 
transpiration. Thus, it resulted in wilting of seedlings (Scafaro, Haynes and Atwell, 2010). Seedlings of cold-frame and hotbed could be transplanted 10 days prior to open as they had earlier true leaf initiation.

At 10 DAT, the height of plants of cold-frame $(7.87 \mathrm{~cm})$ was significantly higher whereas height of plants of hotbed $(5.59 \mathrm{~cm})$ and open $(5.69 \mathrm{~cm})$ were indifferent and significantly lower to cold-frames (figure 4). Afterwards the height of cold-frame and open were at par during 20 DAT, 30 DAT and 40 DAT with significantly maximum height.

Plants heights of hotbed were with significantly minimum after 10 DAT. At 50 DAT, plants of cold-frame $(97.93 \mathrm{~cm})$ had significantly maximum height. Plants of hotbed $(76.19 \mathrm{~cm})$ had minimum height whereas height of open $(86.17 \mathrm{~cm})$ was indifferent to both cold-frame and hotbed. Growth of height of open plants ceased after 50 DAT. Increment in height of plants of cold-frame and hotbed continued till 60 DAT. Cold-frames and hotbed raised plants had longer vegetative growth phase whereas in open condition nursery period was longer. Overall life cycle was of similar length. Longer vegetative growth phase resulted in significantly higher height in cold-frames.

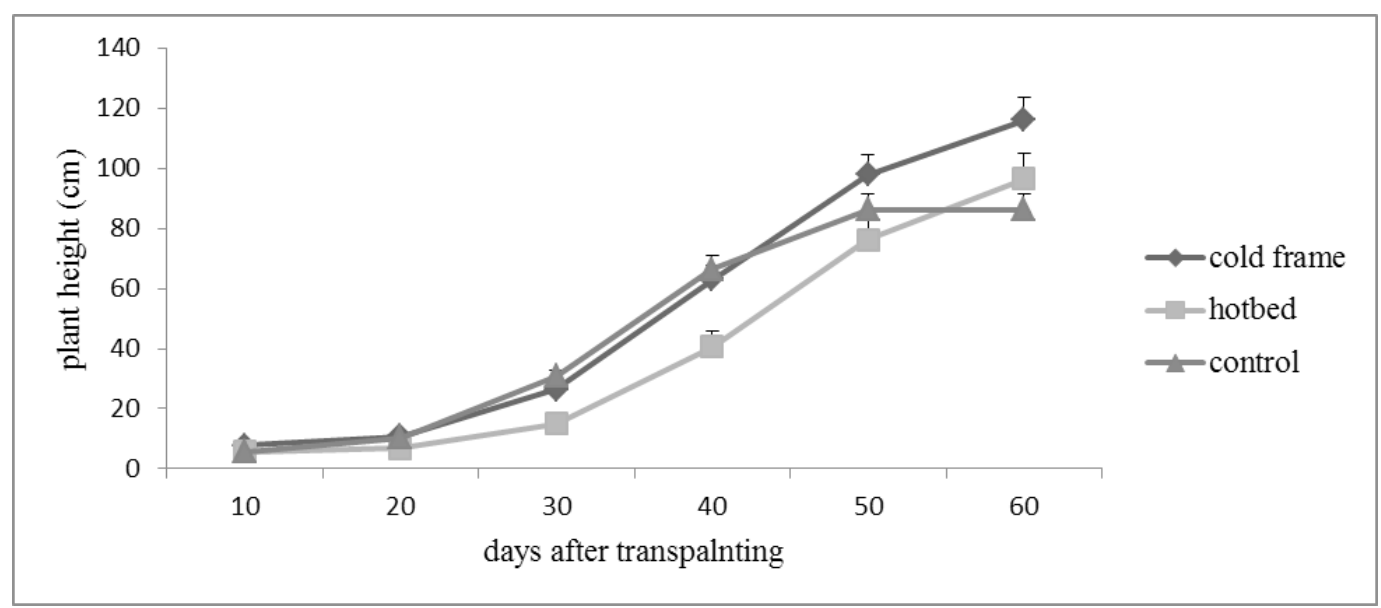

Figure 4: Effect of nursery environment on growth of height of cucumber plants in field condition during Feb, Mar and Apr, 2018 at IAAS, Lamjung

Bulder et al. (1987) reported growth differences found in the mature plants was visible since the early stage of development. After transplanting, cold frame acclimatized quickly to new environment as they were hardy than hotbed and open. Seedlings treated with altering temperature are found to be more resistant (Voronova, 1950). Higher plant height after 20 DAT of open might have resulted due to its lower requirement of optimum temperature range. Seedling raised on lower temperature has increased cold resistance and also promotes plant growth and development (Sherudilo et al., 2006). Cold-frame plants were indifferent to open during the earlier phages. Hot bed was lagging in its performance, as the fact that they were exposed to temperature shock during nursery. This may have contributed to their slower growth rate. The final maximum height of cold frame plants was caused by the optimum growing condition. Although open plants showing profuse growth initially, their growth phase was shorter than cold frames and hot bed. Growth, expressed as dry weight, leaf area or stem length increment at $28-35^{\circ} \mathrm{C}$ in cucumber plants (Karlsen, 1978: Grimstad and Frimanslund, 1993). Optimum temperature for plant growth can change with plant age (Went, 1945). The older the plant, the lower is the temperature that leads to maximum growth (Seginer et al. 1994). High rate of development of non-perennial crops results in smaller plants (Hatfield et al., 2008, 2011), Talanov et al. (2005) examined effect of high and low temperature of a habitat $\left(35\right.$ and $\left.15^{\circ} \mathrm{C}\right)$ and day duration 
$(8,12$ and $16 \mathrm{~h})$ on changes of efficiency rate of $\mathrm{CO}_{2}$ assimilation by cucumber plants that low temperature and a short day increased the value of this rate and simultaneously decreased the weight of biomass of the described plant. So final height attained of open was minimum to both.

Days to tendril initiation was significant lower for plants of cold-frame (57.35 days)(table 1$)$. Plants of hotbed (64.03 days) and open (65.73 days) were at par with significantly higher days to tendril initiation. Plants of hotbed and open were indifferent to initiation of flowering. Days to initiation of flowering were significantly higher for plants of hotbed (71.07 days) and open (71.23 days), both being indifferent. Days to flowering were significantly minimum for plants of cold-frames $(66.87$ days). Plants of hotbed (87.56 days) and open (85.95 days) were at par with significantly maximum days to first harvest whereas cold frames (82.83 days) had the minimum days to first harvest.

Table 1: Effect on yield and yield attributing parameters of plants of different nursery environment during 2018 at IAAS, Lamjung

\begin{tabular}{lllllll}
\hline Treatment & $\begin{array}{l}\text { Days to tendril } \\
\text { Initiation }\end{array}$ & $\begin{array}{l}\text { Days to } \\
\text { flowering }\end{array}$ & $\begin{array}{l}\text { Days to first } \\
\text { harvest }\end{array}$ & $\begin{array}{l}\text { Average } \\
\text { length of } \\
\text { fruit }\end{array}$ & $\begin{array}{l}\text { Average } \\
\text { diameter } \\
\text { of fruit }\end{array}$ & Yield \\
\hline Cold-frame & $57.35^{\mathrm{b}}$ & $66.87^{\mathrm{b}}$ & $82.83^{\mathrm{b}}$ & 17.54 & 5.66 & $1348^{\mathrm{a}}$ \\
Hotbed & $64.03^{\mathrm{a}}$ & $71.07^{\mathrm{a}}$ & $87.56^{\mathrm{a}}$ & 17.77 & 5.61 & $1141^{\mathrm{ab}}$ \\
Open & $65.73^{\mathrm{a}}$ & $71.23^{\mathrm{a}}$ & $85.95^{\mathrm{a}}$ & 17.16 & 5.47 & $866^{\mathrm{b}}$ \\
Significance & $* *$ & $* *$ & $* *$ & $\mathrm{NS}$ & $\mathrm{NS}$ & $* *^{2}$ \\
LSD & 2.88 & 2.565 & 2.571 & 1.037 & 0.2865 & 304.2 \\
SEm(+/-) & 1.43 & 1.278 & 1.276 & 0.515 & 0.1422 & 146.7 \\
CV\% & 5.0 & 5.2 & 4.3 & 9.8 & 5.4 & 35.1 \\
\hline Grand Mean & 62.37 & 69.72 & 85.44 & 17.49 & 5.58 & 1119 \\
\hline
\end{tabular}

The nursery condition had prolonged impact on the development stage as the same sequence in development stage is followed in tendril initiation, days to flowering and days to harvest. Hotbed after the stress condition had delayed development stage. The optimum temperature range for plants of open was lower than for cold-frames. Higher temperature might have enhanced early fruit growth at the expense of vegetative growth (de Koning, 1988). The pattern of difference in days of growth stage was thus minimized.

The average length of fruit and diameter of fruit was not significant. The yield per plant was highest for cold frame (1348 gm) and lowest for open (866 gm) with hotbed (1141 gm) indifferent to both cold-frame and open. Open plants yielded 35\% lower than cold-frames. As the morphology was indifferent, number of fruits affected the net yield. The effect of the size of the fruit sink demand on the photosynthetic rate was explained by Marcelis (1991), who compared photosynthetic rates in cucumber plants with zero to seven fruit per plant. The growth of a cucumber fruit, when not constrained by assimilate supply, the strong increase in growth rate with increasing temperature more than compensates for the reduction of fruit growth period, resulting in an increase in marketable fruit size (Marcelis and Hofman-Eijer 1993). The proportional distribution of assimilates among sink is regulated primarily by the sink (fruits) (Evans, 1975: Glifford and Evans, 1981: Farrar, 1988: Ho, 1988: Verkleij and Challa, 1988). Source strength influences the number of fruits on a plant and, therefore, indirectly influenced the dry matter partitioning (Marcelis, 1994). Growth rate is dependent upon the assimilate supply.

As cold-frames plants had profuse vegetative growth, the photosynthetic rate was higher. It leads to higher assimilation of photosynthate in fruits, thus increasing yield. Cold frame plants also had longer vegetative growth phage which further increased net assimilation. In annuals, high rate of development of non-perennial crops results in smaller plants, shorter reproductive duration and lower yield potential (Hatfield et al., 2008, 2011). Fruit development appeared to be closely related 
to the temperature sum. The growth rate increased with increasing temperature, but the effect on final fruit characterstics depended on the level of assimilates supply. As there was difference in number of fruits produced by the treatments, the morphology of fruit was insignificant. The drymatter percentage of the fruits decreases with increasing number of fruits on a plant. The fruit fresh weight production of the fruit increases with increasing temperature, but fruit dry weight production is not affected (Marcelis, 1993).

\section{CONCLUSION}

Initial temperature range provided for cucumber seedling had positive impacts on germination, growth, development and yield. Although the divergence in number of days for growth stages was fluctuating, seedlings grown in optimum temperature range yielded earlier with high yield. At the investment of locally available material, farmers can be benefitted with higher returns of earlier and higher yield. Further prediction of weather can help in the planning of right time for nursery establishment.Cold-frame for raising seedlings of cucumber was found to be better than hotbed and raising seedling in open during winter month of January. Hotbed was found to be providing higher temperature than required in case of climate of Lamjung. Hotbed did cause stress environment during raising of seedlings. Hotbed, although considered superior by farmers in the region, did not achieve significant superiority over cold-frames. The research can be applied for the base of further research in the field. Temperature in which the crop is grown has shown major impact on the growth phrases and the ultima yield. Temperature regulation by microclimate modification- using locally available materials can be utilized for maximizing the production in off seasons.

\section{ACKNOWLEDGEMENT}

Our sincere thanks go to Mrs. Goma KC and Mr. Narayan Kumal who gave access to the equipment necessary for our research. We would also like to thank our friends for their help and support throughout our research, IAAS Lamjung Campus administration for the availability of resources and everyone who helped directly or indirectly during the period of our research.

\section{REFERENCES CITED}

Aykroyd (Dr). (1941). Health bulletin. Nutrition Research Laboratories, Conoour. 23

Bulder. H.A.M., Van Hasselt \& Kuiper,R. (1987). The effect of temperature on early growth of cucumber genotypes differing in genetic adaptation to low-energy conditions. Scientia Horticulturae. 31 (1-2): 53-60

Denisen. E.L. (1979). Principles of horticulture. Macmillian Publishing Co. Inc. ISBN: 0023283807 : 143-145

Kumar, A., Tiwari, G.N., Kumar, S., and Pandey, M. (2006). Role of greenhouse technology in agricultural engineering. International Journal of Agricultural Research. 1(4): 364-372

Marcelis, L.F.M. (1993). Fruit growth and biomass allocation to the fruits in cucumber. 1. Effect of fruit load and temperature. Scientia Horticulturae. 54(2): 107-121

Marcelis, L.F.M. (1992). The dynamics of growth and dry matter distribution in cucumber. Annals Of Botany. 69: 487-492

Markovskaya, E.F., Sherudilo, E.G., \& Sysoeva, M.L. (2007). Cucucmber seed germination: effect and after-effect treatments: Seed science and biotechnology. Global Science Books. 25-29

Russo, V.M. \& Biles, C.L. (1996). Incubation temperature affects changes in cucumber seed proteins and minerals content. Seed Science And Technology. 24. 339-346

Scafaro, AP., Haynes, P.N., \& Atwell, B.J. (2010). Physiological and molecular changes in Oryza meridionalis Ng., a heat-tolerant pecies of wild rice. J Exp Bot. 61: 191-202.

Shoemaker, J.S., \& Teskey, B.J.E. (1969). Practical horticulture. John Wiley And Sons Inc. 168-171

Thompson, H.C., \& Kelly, W.C. (1985). Vegetable crops. Mc Graw Hill Publishing Company Inc. 86-106: 513-523 